\title{
The Silver Darlings: An Emblem of the Scottish Sea and History
}

Les Silver Darlings : emblème de la mer et de l'histoire d'Écosse

Danièle Berton-Charrière

\section{(2) OpenEdition \\ Journals}

Electronic version

URL: http://journals.openedition.org/etudesecossaises/1175

ISSN: $1969-6337$

Publisher

UGA Éditions/Université Grenoble Alpes

Printed version

ISBN: 978-2-37747-001-3

ISSN: $1240-1439$

Electronic reference

Danièle Berton-Charrière, «The Silver Darlings: An Emblem of the Scottish Sea and History », Études écossaises [Online], 19 | 2017, Online since 01 April 2017, connection on 08 September 2020. URL : http://journals.openedition.org/etudesecossaises/1175

This text was automatically generated on 8 September 2020

(c) Études écossaises 


\title{
The Silver Darlings: An Emblem of the Scottish Sea and History
}

Les Silver Darlings : emblème de la mer et de l'histoire d'Écosse

\author{
Danièle Berton-Charrière
}

\section{'Texts' in contexts: preliminary words}

1 In his work entitled Literature in Contexts, Peter Barry recalls that "A context is something specific outside the text which is activated and validated as an explicatory framework by something within the text" (2007, p. 52). Developing and refining the concept, he precises that what "has become the privileged, transcendent signifier of literary studies, universally assumed to be a good thing" remains "a floating signifier" (ibid., p. 22). He therefore tries to make distinctions between various categories of context exerting a form of pressure on the text, such as "broad" and "deep" ones: "the deep variety being the kind which, in addition to the pressure they exert, have specific textual warranty and are unique to the specific work of literature under discussion" (ibid., p. 24). This definition can obviously be extended to the notions of cotextual and transtextual clusters at the core of the second part of this paper. The textus ${ }^{1}$ meanings open the scope of the material to be analysed to several supports and to stage and screen representational forms. Starting from the Latin source of the word, Barry reckons that "perhaps texts should be looked at as "intermittent and extensible structures formed by a weaving together of strands"' (ibid., p. 37). Yet, following Roland Barthes's works, he recognises that these structures "seem to have escaped the web of definition" (ibid.), the observer (reader or spectator) being attracted to textual presence and correlated and interrelated absences.

2 Treating the "question of material base" in his 1986 MLA presentation, J. Hillis Miller reminds that "literary study in the past few years has undergone a sudden, universal turn [...] toward history, culture, society, politics, institutions, class and gender conditions, the social context, the material base" (Veeser, 2013, p. 15). Following these paratextual notions and reflections, this paper presents a context-based approach to 
various artistic works on the silver darlings, whether belonging to the domains of literature such as Neil Gunn's The Silver Darlings, or of cinema and drama with adaptations of Gunn's novel to the screen and to the stage, or of realistic photography, or of history painting, or of popular traditional tales, music and songs, and to other arts such as James Maskrey's glasswork. Through a historical landmarks and selected interrelated semiotic and textual networks, the emphasis will be laid on the dialogical links between reality, legends and art forms, between the force of collective unconscious and the construction of a myth, between an emblematised fish and the identity of a nation.

\section{Precious herring of all times: historical reminders and cultural contexts}

3 Archaeologists reckon that herring has always been a subsistence food and activity to small Scottish fishing communities, even to the people who settled in Scotland around $7,000 \mathrm{BC}$. One of the most used sea resources, herring has provided the nation with a precious, inexpensive, abundant and wholesome food:

The herring is an oily fish. Economically, it has been the most important fish and one of the earth's most used marine resources. Herring has been very important to the Scottish diet. It provided a cheap, plentiful and nutritious source of food. They have been caught off the cost of Scotland for hundreds of years. (historyshelf 01)

Although game and salmon catching was conditioned to the restrictions imposed by land and river owners and by laws, maritime herring fishing was free. The sea could be compared to a reliable feeding mother securing her children when necessary, and to a generous provider that could also enrich them with her own natural wealth. Yet, her resources are not eternal and this, the Scots have learnt at their own expense.

By the Middle Ages, fishing was a natural industry and herring was exported to continental Europe. The many Scottish religious houses then granted exclusive fishing rights and demanded their part of their tithes in fish. Over the centuries, the trade developed encouraged by the Crown and the Government that "granted licences to catch and market fish, and provided bounties for boat-building and for the curing of herring" (historyshelf 01). The business rapidly increased from 1808 onwards due to private as well as governmental initiatives and schemes, despite the competition with the Dutch and Norwegian fishermen whose methods were more intensive. Earlier, Pieter Vogelaer had already illustrated an impressive army of "herring busses" escorted by a naval vessel in his work entitled The Dutch herring fleet (Hollandse haringvloot). This ink on panel dated between 1656 and 1730, renders the power of the industry through the precision of his pen. The numerous boats, their crew and drifting nets are very neatly graph designed.

At the beginning of the 17th century, a 1614 English account praised the herring trade:

The Hollanders do make both a profitable and a pleasant trade of this Summer fishing. For there was one of them that having a gallant great new Buss of his own, and he having a daughter married unto one that was his Mate in the Buss: the Owner that was Master of this Buss did take his wife with him aboard, and his Mate with his wife; and so they did set sail for the North seas, with the two women with them, the mother and the daughter. Where, having a fair wind, and being fishing in the North seas, they had soon filled their Buss with herrings; and a Herring-Yager cometh unto them, and brings them gold and fresh supplies and copeth [bargaineth] 
with them, and taketh in their herrings for ready money, and delivereth them more barrels and salt; and away goeth the Yager for the first market into Sprucia [Prussia]. And still is the Buss fishing at sea, and soon after again was full laden and boone [bound] home: but then another Yager cometh unto him as did the former, and delivering them more provision of barrels, salt, and ready money, and bids them farewell. And still the Buss lieth at sea, with the mother and daughter, so long, and not very long before they had again all their barrels full; and then they sailed home into Holland, with the two women, and the Buss laden with herrings, and a thousand pounds of ready money. (An English Garner, vol. 4, p. 345)

7 In a letter dated 31 July 1792, Count Zenobio mentions the commercial rivalry between the Dutch and the Scots. He states the problems related to the importation and exportation of preserved herring and asks for "the red herrings ${ }^{2}$ of Scotland to [be sent to] the Venetian and Italian markets, as Dutch herrings are no longer transmitted to those parts":

Sir, [...]

I begged him to give orders to send me some barrels of red herrings, caught and cured in Scotland, with the price it will cost, delivered at Venice, to try, if the price and the quality are equal, or better than those of Holland (Taymouth, 31 July 1792). (Sinclair, 1831, p. 3)

8 In his travel journal, Daniel Defoe himself praised what he called 'the prodigy', describing the shoal in the waters as 'one third water, and two thirds fish' (1983, p. 301). In 1738, he also described the Yarmouth Free fair (fishing fair) that lasted from Michaelmas to Martinmas from 29th September to 11th November. From the twelfth century onwards, Great Yarmouth in Norfolk was known as the centre of the herring trade (Kingshill \& Westwood, 2014). Defoe mentions four million herring taken in one season (in Yarmouth and Lowestoft). He is astounded at their incredible prodigious quantities and at people's diet more particularly. The consumption of herring has long been associated with religious rites, Lent to mention but one. Yet, current fishing, trading and eating habits became interrelated, intertwined and interwoven as strands. They were also meshed with political backgrounds:

[...] before the Reformation when people were expected to have fish rather than meat on Wednesday, Friday, Saturday and during Church fasts. In Lent 1265, the Countess of Leicester's household consumed up to a thousand herring daily, and in the year 1307-8, Durham Priory bought 242,000. Cheap and plentiful, herring remained a staple food in Britain until 1951, when the catch dropped so catastrophically that a ban was imposed on North Sea herring fishing. (Kingshill \& Westwood, 2014)

9 The evolution of the profession was hastened through financial aid and technical progress. Crews and owners were motivated by profit and new prospects. In the 19th century, a bounty of $£ 3.00$ per ton was allowed to owners of over 60 -ton herring boats, as well as a bounty on all herring sold abroad. The market also expanded through the development of railways permitting quicker deliveries. According to seasons, fishermen worked off the east coast (in winter and spring), the north coast of Scotland and Shetland (in summer) and off East Anglia (in autumn). Through the growing numbers of vessels, the industry became the largest in Europe.

In 1907, 2,500,000 barrels or 250,000 tons were cured and exported. In 1913, there were 10,000 Scottish boats that followed the shoals. Because herring is a fat fish, it was necessary to cure it rapidly. From the age of 15 or 16, numerous 'herring lasses' gutted and packed the catches, which can be seen on sepia photographs (girlmuseum). They pose, with their headscarves on and sleeves up, smiling and laughing, in front of long 
tables covered in fish (Scottishmuseum) or next to big barrels (girlmuseum). Donald Murray shows some similar black and white family pictures in his newspaper article on the sea adventures of the 20th century Scottish female gutters.

11 Were called "Herring girls (or herring lasses) [...] groups of women who would travel the east coast of the United Kingdom from as far north as Aberdeen to as far south as Great Yarmouth, following herring as they migrated throughout the year (EAFA)". On sepia or black and white archive films (EAFA), one can see their working conditions. As soon as the boats unloaded the catches, the women worked mechanically, as fast as machines, with their bare hands manipulating sharp knives and salt, and their bending bodies half disappearing into the barrels where they laid the salted fish:

Women worked in groups of three or four, gutting and salting, each group packing one barrel at a time. The women were paid depending on the amount of barrels they finished, so it paid to work fast. The work was all outside, so it could be freezing cold in the winter. Standing in a quagmire of mud and fish guts (imagine the smell!), the women worked with sharp knives to gut the fish, which could cause injuries, and combined with the salt and brine, the work could be very painful. It was also extremely tiring - the women had to work for as long as it took to gut and salt the whole day's catch, which could be up to fifteen hours a day. It would have been scary for some. Some girls started work at sixteen. The women would often be away from home for months at a time. Some of the herring girls from the Scottish islands may not even have spoken English, only Gaelic. However, working in the herring industry gave these women huge amounts of freedom to travel and work, increasing their independence and confidence. Some crews travelled and lived together for a whole season, instilling a huge amount of camaraderie and community in the group. (girlmuseum)

Working long hours and days, in the cold and stench, with burning and painful hands and backs at an ever quicker mechanical pace was surely worse than assembly-line employment. Despite the difficulties they had to cope with, women gained some forms of liberty and autonomy. They travelled, earned money, and somehow felt independent.

Locally, the curers purchased the cashes through a system of engagement:

With the engagement system, the curer agreed to pay a fixed rate for every cran (a measure of fresh herring) landed from each boat during that season, up to a maximum of 200 or 250 crans. [...] It created a system of guarantee and stability that was fundamental to the Scottish herring fishery. However, the curer did have to anticipate the market, and there were years in the late 19th century when curers lost a lot of money. (historyshelf 13)

The rapid increase of the industry and the development of boats were necessarily correlated. The design of the vessels changed, and wind-powered at first, they then used steam, diesel and petrol as fuel. Some fishermen directly converted their sailing hulls to motor because it was an easier change. To compensate for the loss of space caused by engines and machinery, decked vessels were created. Progress also influenced the evolution of the nets and methods used to produce more and reduce the perils known at sea (historyshelf). Archive black and white silent films show these evolutions through fixed shots or very slow camera movements.

Historical events such as the Napoleonic wars or World War I and II affected the herring trade. In The Silver Darlings, Neil Gunn evokes post conflict periods when prosperity boomed: "It was the end of the Napoleonic era. For the Moray Firth it was 
the beginning of the herring fisheries, of a busy fabulous time among the common people of that weathered northern land." (1941, p. 14)

The clearances and their correlated evictions did change crofters' lives too, dragging them towards the sea-coast for survival and subsistence. Their ordeal and the historical context leading to their migrating are often referred to in paintings, novels and plays. In his stand-up show entitled "The Return of the Ginger Step-Kid AKA; STAND UP, HAGGIS! AKA The Last of the McSporrans. A 'play' by 'Henry Adam"' (7 April 2013), the author ironically recalls this bleak period:

From Caviar to cod roe to Farmfood's fish sticks in less time than it takes a Gti to go from nought to sixty. The untold tragedy of one of Scotland's greatest clans.

We struggled on of course, staying close to the beaches, surviving on what we could pick there, cooking our moss and whelk chowder on the residue of washed up twigs and fishboxes, fighting the skorries for every bite.

There was plenty of land inland of course, beautiful land, arable and sheltering compared to where we were now, but it had all been bought up by a bunch of English sheep, and we watched with jealous eyes from the edge of the links these fat bloated woolly bastards arrogantly munching on the fine grass and succulent thistles that were ours by right of birth. That's when the men with the Bibles came, preying on our despair, and we got on our knees and prayed on the beaches for God to send us Salvation, but God must have been out of salvation that week, because he ended up sending herring instead.

Herring!

We raced into the sea with our nets of spun spiders silk-we had a lot of time on our hands remember?-and plucked those silver darlings, one by one, from the glittering surf.

We plucked them and plucked them and plucked them and plucked them, then we plucked them a little more, and a few more besides, til[1] even the none too bright herring realised that this plucking wasn't going to end any time soon, and plucked off themselves, probably to share an environment with some less greedy pluckers, who wouldn't pluck a gift fish in the mouth.

Well the herring left us on the beach, same as the credit crunch did in 1815. It was our own fault really. We were greedy pluckers. 60 years of living on moss and whelks does that to a man. We distrusted tomorrow so we plucked for all we were worth today. It was a plucking orgy, and when it was over there was nothing left to do but put our clothes on and go home. Only we had no clothes. And the sheep were still living in our home, smug bastards, eating our Heather, although Heather wasn't complaining. Slag. (Unpublished playtext, with Henry Adam's permission.)

In the past, herring and cod provided Atlantic Europe with most of its protein. Herring was once incredibly abundant and although the name of this species may have different origins (The American Heritage Idioms Dictionary), ${ }^{3}$ the Old German word for it meaning 'multitude' shows why the fish attracted thousands of boats from all over Europe to the Scottish waters. At the peak of the herring industry growth, Britain exported a quarter of a million tons a year. Small and tasty, people used to fry, smoke or cure them. Herring saved some unfortunate Scots' lives and made other more privileged and lucky ones rich. Yet, there was an end to this god-sent manna. So to speak, men killed the goose that laid golden eggs. Years of bans and hardship came as the retribution of their greed and folly. 


\section{The silver darling: 'a fish of legend and song'}

18 Silver-coloured, as slick and bright as mercury, the fish has poetically and affectionately been nicknamed 'silver darlings' in Scotland. This may also refer to the prosperous activities it permitted for centuries: "The money will be flowing like the river. As one man said in Wick: the creels of silver herring will turn into creels of silver crowns." (Gunn, 1941, S. D., kindle edition)

19 The "silver darlings" expression was chosen by Neil Gunn as the title of one of his novels (1941), by Peter Arnott's for its dramatic adaptation and for Clarence Elder's film (1947). The prodigious past of the herring trade and the decrease of the natural food resource ${ }^{4}$ magnified its legendary dimension through folklore, songs and stories. The National Museum of Scotland exhibited a piece called The Last of the Silver Darlings by glassmaker and storyteller James Maskrey in 2014. Through its renaming, the fish was endowed with an iconic and aesthetic scale. Through circulation, the "contexts of (re)production' strand of contextuality" (Barry, 2007, p. 39) opens up the scope, "context meaning larger contextual frame of reference" (ibid., p. 38). Socio-linguistic echoes and imprints, whether in Gaelic or Scots, resound in memories as forever engraved and indelible marks. The silver darlings conjure up, denote and connote the Scots' memory, history, resistance, and identity. The darling designation also renders the affection and gratitude they felt for the species in their fight for survival. Through centuries of struggle, it has become a symbol of resistance. It helped them live on through periods of victimization, the clearances being the best known. Despite large numbers of Scots emigrating to the "new world", many crofters outlived the English colonial greed by flying towards the coasts; they resisted fed on fish and other sea-shells and kelp.

It could be tempting to think of the analogical link with the first representation of Christianity. ${ }^{5}$ Yet, what is sure is that "silver darlings" have always been part of the Scots' History and life, traditions, customs, culture, symbolism and imagery; the "herring-bone" pattern is currently used in masonry, skiing and slope climbing (Chambers Dictionary, 2016, p. 752). It belongs to their past and cements the generation links. In everyday language, the "herring" can be metaphorical. In their book, Sophia Kingshill and Jennifer Westwood mention a few proverbs and catch-phrases using the word "herring": for example, "to throw a sprat to catch a herring" or "herring gutted" to describe a very thin man, or "to draw a red herring across the path" that is to say to distract from a subject by raising a side issue. There are about two dozen sayings that could be cited.

Despite its quantity and currency, the silver darling is no ordinary fish: in legends and tales, it is introduced as "the King of the Sea". Not far from Scotland, there is a Manx story explaining how herring was selected by the other fish to be their king. In Manx Fairy Tales, Morrison suggests: “And, maybe, it's because the Herring is King of the Sea that he has so much honour among men. Even the deemsters, when they take their oath, say: 'I will execute justice as indifferently as the herring's backbone doth lie in the midst of the fish." (1911, p. 26) She explains that the "Manx people will not burn the herring's bones in the fire, in case the herring should feel it. It is to be remembered, too, that the best herring in the world are caught in this place off the Shoulder, where the fish held their big meeting, and that is because it is not very far from Manannan's enchanted island." (Ibid.) As a genre, the magic of tales and ballads counters and 
overwhelms reality, but the fable-like stories are didactic. The herring's royal status is celebrated in songs:

oh! the herring, boys, the herring,

Oh! the herring, boys, for me!

Red or kippered, fresh or pickled,

Oh, the herring is king of the sea! (manxnotebook)

One could suggest that, affirming the kingly position of the symbolic herring, subtly elected in tales, could be understood as questioning the supremacy of the English on the seas, a renowned domination they have had since the Renaissance. Counterbalancing their ascendancy in tales is subversive but politically correct: the context of the magic island and the fairy-tale genre serve as secure screens.

The lyrics mingle down-to-earth considerations about the fishermen's labour, and about religious faith and gratitude:

Up with the lug, and let her run

Before the wind and tide;

The gannets plunge, the gulls keep watch,

The herring shoal is wide.

$[\ldots]$

Admiral Quirk has struck his flag,

So down with the nets, and pray

The fisher's Friend to bless our homes

And toil by night and day. (A Book of Manx Songs)

In the traditional Scots The Harrin's Heid [The Herring's Head], by the band called Folly Bridge, the lyrics and chorus detail the various parts of the fish in which nothing is lost:

THE HARRIN'S HEID [Herring's Head]

Oh, what'll we dee wi the harrin's heid?

Oh, what'll we dee wi the harrin's heid?

We'll mak it inte loaves of breed,

Harrin's heid, loaves of breed,

And all manner of things.

of all the fish that's in the sea,

The harrin is the one for me.

How a ye the day? How a ye the day?

How a ye the day, me hinny-o?

Oh, what'll we dee wi the harrin's guts?

Oh, what'll we dee wi the harrin's guts?

We'll mak them inte a pair of beuits,

Harrin's guts, a pair of beuits,

Harrin's heid, loaves of breed,

And all manner of things.

of all the fish that's in the sea,

The harrin is the one for me.

How a ye the day? How a ye the day?

How a ye the day, me hinny-o?

Harrin's fins, needles and pins.

Harrin's tail, a boat that sails.

Harrin's eyes, puddins and pies.

Harrin's scales, a barrel of ale.

Harrin's belly, a lass called Nellie. (Traditional, anon.)

A Youtube version presents a video with period photographs showing men and women working: some fishermen aboard their boats, hauling their nets; others on the quay; 
women either salting the fish or knitting while waiting for their fathers, husbands and sons, the steam- boats and their crews, active.

Silver darlings are both legend and reality, tale and toil. Common and ordinary, the fish has grown into the symbol of Scotland's culture and History.

In a newspaper article entitled "The resolute fishermen of Scalpay in the Outer Hebrides still dream of a simple fish of legend and song" (the Anglers Journal), Johan Hallberg-Campbell recalls memories of his childhood, when he used to visit his Scalpay Gaelic-speaking fisherman uncle. To the little boy, the far-away island where he was born, but which he had to leave at five, had become a strange, mysterious and magical place, with unknown specificities to discover, with some thrilling and fascinating storytelling, with enchanting and enrapting music and language. The infant's mind created a world of fancies tinged with the surreal atmosphere oozing from adults' discussions he couldn't understand:

I had heard much about Scalpay. My family is from Scalpay. My father was born there, and he and his family left when he was 5 years old.

To me, the island was like a fairy tale, an unknown land, far away on a distant planet, with stories of crofts, religion and herring fishing.

My Uncle David Morrison has lived his entire life on Gaelic-speaking ScalpayNorse for "scallop island"-on the east side of the Outer Hebrides, about 35 miles from the Scottish coast. The island is just 4 kilometers long-one of 15 in the archipelago that are inhabited.

I first visited Scalpay several years ago to see my relatives and to see for myself where I had come from. When I arrived, I was told that there had been no births for seven years and that the fishing traditions and the people who had kept them alive were fading away, too. (The Anglers Journal)

Paradoxically, the fairy-tale island where Johan Hallberg-Campbell's relatives live is no fairy-land: "Over the years, its population has shrunk to 250. A third of the islanders are pensioners. The rest cling tenaciously to fishing or crofts-small tenant farms-to earn a living in what most people would say is a harsh and unforgiving environment." (Anglers Journal) His uncle David recalls past times, his life as a fisherman, periods of prosperity and the decline of the activity:

Uncle David talks of the prawn fishing-hard, unpredictable, modest in its financial return-as a painful plummet from the 1960s and '70s, when Scalpay's fishermen were infected with "herring fever." Back then, he ran the powerful ring-net fishing boat Hercules, which hauled in tons of "silver darlings," as herring-a fish of legend and song-were called. The vessel would go to sea for days at a time and net my uncle and his six crew members a tidy profit.

In those halcyon times, villages such as Scalpay that had a strong fishing tradition thrived, while those that didn't depend so much on the sea's bounty declined. Before the stocks dwindled, the herring fishery supported not just the village economy, but also a way of life and a vibrant network of buyers, sellers, harvesters and processors, who forged a strong bond and formed a caring community that looked after one another. (The Anglers Journal)

The old man regrets the traditional mode of living that has almost disappeared on the island:

The collapse of fishing - the traditional livelihood of many of Scalpay's men-has led to the collapse of a way of life here and elsewhere around the world. These coastal and island communities can hardly sustain themselves as more and more young people leave their home and heritage to look for work. Dependent on the ocean and traditional fishing methods, they are being swallowed by the modern world. (The Anglers Journal) 

coastal life and identity of the Scots; it merged all the joys and pains felt in their relation to the sea; it combined the hopes and hardships the men and women were submitted to in difficult landscapes and times; in their minds, it engraved the memories of the dead engulfed by untamed waters.

31 And now, what remains of the past prosperity is mainly cultural. Silver darlings are part of the myths Scottish identity is fed on. In his work on Neil Gunn, Philippe Laplace wrote about the author's trilogy as founded on the collective beliefs and stories linking generations and times, political systems included: "Après le territoire dans Sun Circle, l'histoire dans Butcher's Broom, c'est la fonction qu'assument les mythes, les légendes et les traditions qui constituent la clef de voûte de The Silver Darlings [...] Les mythes, légendes et traditions facilitent l'intégration des communautés gaéliques à ce nouvel univers capitaliste." (Laplace, p.158) After the collapse of the trade, herring related behaviours and traditions somehow lived on, one way or another, in everyday habits or in people's memories, hearts, poetical, musical and oral expressions: "Les anciennes traditions, même si elles avaient perdu beaucoup de leur influence, n'avaient pas totalement disparu dans les communautés du Caithness. Gunn semble donc suggérer qu'il suffisait de sortir les habitants de leur léthargie afin d'assister à la renaissance de ces habitudes culturelles." (Laplace, p. 164) These cultural references and customs intertwine sociological, mythological and aesthetic lines and contents. Through an onomastic analysis, Philippe Laplace demonstrates how myths, whether Celtic or other, ooze from the fibres of the text.

Neil Gunn's Silver Darlings is very well documented: the author relied on the expertise and experience of professionals and authors of technical books on the subject of herring fishing and Scottish fisheries. The historical dimension and the writer's commitment are studied by Philippe Laplace in detail in his book entitled Les HautesTerres, l'histoire et la mémoire dans les romans de Neil M. Gunn. Somehow a family saga, Gunn's trilogy corresponds to what Peter Barry defines as deep context:

One of the 'deepest kinds' of contextuality occurs when a group of texts by the same author form a recognised 'cluster', so that the cluster as a whole constitutes a distinct 'textual domain' with its own integrity and cohesion, while the individual items in the 'cluster' contextualise each other, exhibiting a range of recurrent patterns, concerns and motifs. (2007, p. 52)

Yet, a more panoramic or "broad" contextuality tends to make the reader travel from and to Gunn's texts. It facilitates the reading of the text. Set in a specific period of Scottish History, and rather faithful to facts and figures, Gunn's fiction renders the spirit, manners, and social conditions of the time through some down-to-earth details: "Now with the four-shilling bounty and the price per cran to which Roddie had agreed, he could not for the life of him see a smaller profit than ten shillings a barrel, and it might well be a shilling or two more. But even at ten shillings on 800 barrels his profit would be $£ 400 . "$ (1941, S. D., p. 77)

To the essential matter-of-fact and sensible line of his novel, Neil Gunn added touches of what Man cannot rationally explain like prophetic dreams, premonitory visions and deep emotions. Through them, the Scottish tale-telling tradition and the influence of ballads tend to surface. These components have been kept in the various hypertextual versions despite the changes imposed by generic transpositions.

The characters seem to accept a form of determinism and the attraction of the sea is impossible to resist. Catrine hates the lethal sea: "He knew why his wife hated the sea, 
but she needn't have gone to such lengths to show it. That first winter had been a terror. For one long spell, they had had little or nothing to live on but shell-fish and seaweed. Often they ate the wrong thing and colic and dysentery were everywhere." (Gunn, 1941, S.D., p. 13) Tormad's wife is obsessed with her uncle's death. The preying sea seized him and kept his body: "They had cleaned the shore to the lowest edge of the ebb, and one day, following the suction of the receding wave, he slipped, and, before he could get up, the next wave had him and sucked him over a shallow ledge. His arms lathered the water for a moment while horrified eyes watched. Then he sank and did not come up." (Ibid.) Like an enormous mouth, the sea swallowed him with a suction sound of greedy satisfaction.

The sea fascinates men and terrifies women. Catrine cannot convince her young son Finn to keep away from its waves and from fishing. She is desperately fighting against her natural rival that engulfs so many boats and men whatever their ages. Yet, Finn will prove strong and mature in his 16th year: the sea has made him a man. Paradoxically, the sea is both a source of life and death: "Yet it was out of that very sea that hope was now coming to them." (Ibid.)

Neil Gunn's nationalist and realistic novel has been adapted to the stage and to the screen. As Barry recalls, transtextuality can relate different genres and media: "Structural and semiotic analysis, and structuralist founding texts like Barthes's Mythologies put forward precisely this expanded notion of textuality, by analysing advertisements, packaging, film images, and so on, in a very illuminating manner." Barry mentions "the triad of text, context and intertext" (2007, p. 36).

Peter Arnott's adaptation of Neil Gunn's novel rests on the force of the author's political statement. In his review, Ross Kinghorn wrote:

The degree to which our lives are (mis)shaped by the financial opportunism of others has become more transparent in recent times, though soon it will naturally go back to hiding, thanks to Gordon Brown's G20 decision to lay down no serious banking regulations. It's this kind of political cowardice that makes those who work to keep the history of economic exploitation alive all the more important. Among their number is Neil M. Gunn, whose 1941 novel is here given the theatrical treatment by Aberdeen Performing Arts. (Kinghorn, TVBomb).

Similar lessons and messages delivered to today's audiences through theatrical productions were in large numbers just before the 2014 Scottish referendum on independence. This has always been the function of drama and theatre. Alistair Beaton's Caledonia based on the 1698 Darien expedition, points at the social, political and financial disasters engendered by greed and colonialism. Though different in their topics, the two plays reveal the same faults and correlated consequences on Scotland.

The Scotsman review of the play insists more on the emotional and epic popular dimensions of Gunn's adapted story, a sort of Bildungsroman:

Neil Gunn's 'The Silver Darlings' is an epic adventure story, and one of the best loved Scottish novels of the 20th Century. Set in the early days of the herring fisheries around the Scottish coast, it combines human emotion with stormy seas in the story of a boy growing to manhood, of a man and woman finding love in the face of tragedy, and of a community recovering from the Highland Clearances to forge a new way of life from the forbidding ocean. (Scotsman)

41 The stage version had to be shortened and choices had to be made. As always, when well-known texts are adjusted to the theatrical space and requirements, reviewers 
disagreed on the final form. Some praised the force of the director's work and of the actors' performance:

Strong, unflashy retelling of classic Scottish novel.

Peter Arnott's adaptation of Neil Gunn's classic Scottish novel, telling the semimythic story of a people driven from their North-Eastern lands into the early, often dangerous fishing industry is a nuanced and moving (if necessarily truncated) version of the novel. (Fringe festival article)

Kenny Ireland's staging uses stylisation that's effective but never flashy to tell his story, and the performances are universally enjoyable, with Lesley Hart's put-upon, fragile yet strong mother a particular highlight. (The List)

Philip Fisher, as for him, appreciated how the theatrical production rendered the social historical dimension of Gunn's source text:

The real value of this book, stylishly staged by Kenny Ireland, lies in the picture of this lost people, whose individuality will long ago have been subsumed by the twin evils of emigration and mass media [sic]. (P. Fisher) of the characters' sensitivity and feelings. They didn't welcome the director's options as far as acting and theatrical devices were concerned:

The difficulty Peter Arnott had in adapting a 600-page novel for the stage is apparent in the first half, with exposition and character development moving too fast to form an emotional engagement with the piece. It's not helped by director Kenny Ireland leaning too heavily on cinematic devices, from slo-mo fight scenes to Mathew Scott's crass Hollywood soundtrack. (Kinghorn)

[...]

The second half tones it down, allowing the solid ensemble to get grips with the meat of the play; but as Catrine learns to allow her son to choose his own path, and we feel the familiar theme of letting go of the past creep in, you can't help but feel Arnott has teased out the more trite aspects of the source material, resulting in a kind of irony; it's precisely not letting go of the past that makes Gunn so valuable to us. (Kinghorn)

In the Guardian, although reviewer Mark Fisher agrees about the disturbing pace the first part of the play was performed in, and about the difficult truncating of the source text, he praises both staging and acting, as well as the rendering of the contextual atmosphere and spirit:

These themes come into focus in the second half of Peter Arnott's adaptation when, after a frantic first act that never settles, Meg Fraser's sturdy Catrine finds independence from her past, her hot-headed son and her own emotional repression. Kenny Ireland's production, staged on Hayden Griffin's set of layered volcanic rock backed by projections of period photographs, is excellent on ensemble atmosphere, the 10-strong company acting as a chorus and reminding us of the community's interdependence. The demands of compressing a long novel make it an uneven evening, but one that settles into a touching portrait of the survival of the spirit. (Mark Fisher, 8 Sept. 2009)

On another representational support, the 1947 black and white film directed by Clarence Elder and starring Clifford Evans, and Helen Shingler, offers a screen adaptation of Neil Gunn's novel. As an informative doubly contextual "paratext" the 2006 Shipman Productions used the following abstract for their DVD back cover:

A two-year labour of love by writer and director Clarence Elder and star and associate director Clifford Evans, The Silver Darlings is a sincere and stirring tribute to the men who forged the Scottish fishing industry with raw courage, 
determination and vision. With its stunning use of natural Highland location, it also

offers a visual celebration of the Scottish coastline that has seldom been equalled. recréer la réalité devant les yeux du spectateur et, par là, d'agir sur son intelligence et sa sensibilité.' En effet, l'expérience prouve que le simple enregistrement d'une réalité confère à cette réalité une capacité d'émotion qu'elle n'exprime pas hors de l'écran." (Séquences, "Le réalisme au cinéma", p. 10) Generally said to be based on mimesis, even realistic and naturalistic artworks add an aesthetic dimension through the artist's creation and technique. As André Bazin put it: “La réalité n'est pas l'art, mais un art 'réaliste' est celui qui sait créer une esthétique intégrante de la réalité." (Ibid.) symbolises. It may reproduce, but it always produces something different as Louis Marin explains in Détruire la peinture. Talking about Caravage, he insists on the essential narrative quality of art-pieces, on their story/tale/history telling:

Les textes glissent, dérapent les uns dans les autres en se répétant : la surface, essentielle, dit le Maître; le critique: le fondement, le fond, la profondeur par le dessin, par l'art (lequel ?) ont partie liée à l'histoire, au récit. Noblesse et excellence, savoir raconter, savoir raconter le mort en image ou peindre le vif: la noblesse du sujet ou le vif de l'objet; faire revenir les morts, narrer l'histoire, tisser les figures sur la scène ou voir ce qui est ici maintenant devant l'œil. Et pourtant le Maître a dit : la surface. (Marin, 1997, p. 12) 
51 relate, recall and commemorate. Besides, the translation process from one artistic and cultural object to another with the same "material base" opens intersemiotic possibilities.

52

Inspired by Scottish History, glassmaker and storyteller James Maskrey created a series of freeblown jars entitled The last of the Silver Darlings. Although they are topped with fancy button-lids, they could be compared to mono- and poly-chrome fine designed fishbowls enclosing a "dead" glass herring at the bottom. The paratextual title of the artist's work indicates a clear historical context. De facto, through this denomination, these pieces belong to the broad intersemiotic and interlinguistic silver darlings cluster.

James Maskrey's double artistic expertise, as a Caithness glassmaker and a tale-teller fascinated by Scottish History, offers a precious museum-preserved reliquary to the nation's past, as well as to her symbolic fish and trade. As such, the urn-like exhibits help keep their memory alive. They can also be regarded as didactic reminders of national greed and folly, a lesson to bear in mind for future generations. Included in a transtextual cluster, James Maskrey's works complete a form of inverted ekphrasis, and parodying Horace's coined phrase Ut pictura poesis, we could talk about Ut sculptura poesis.

Beyond the dialogical exchanges intersemioticity and intertextuality recognize and develop, reciprocal relations between texts and contexts enlarge and enrich the informative networks of meaning and interpretation. Appropriate methodologies help decipher their codes, search the recesses of their discourses, and follow the strands of their material base as Aram Veeser explains:

The writing and reading of texts, as well as the processes by which they are circulated and categorized, analyzed and taught, are being reconstrued as historically determined and determining modes of cultural work; apparently autonomous aesthetic and academic issues are being reunderstood as inextricably though complexly linked to other discourses and practices-such linkages constituting the social networks within which individual subjectivities and collective structures are mutually and continuously shaped. [...] However, the prevailing tendency across cultural studies is to emphasize their reciprocity and mutual constitution: on the one hand, the social is understood to be discursively constructed; and on the other, language-use is understood to be always and necessarily dialogical, to be socially and materially determined and constrained. (Veeser, 2013, p. 15)

\section{BIBLIOGRAPHY}

\section{Books}

ARBER Edward (ed.), 1882, “Typical Case of a Dutch Family Fishing”, in An English Garner, in Gatherings from our History and Literature, Birmingham, FSA \& c., vol. 4. 
BARRY Peter, 2007, Literature in Contexts, Manchester, Manchester University Press.

DEFOE Daniel, 1983, A Tour through the Whole Island of Great Britain [1724-26], London, The Folio Society, vol. 3.

GunN Neil, 1941, The Silver Darlings, London, Faber \& Faber, paper edition and kindle edition.

LAPLACE Philippe, 2006, Les Hautes-Terres, l'histoire et la mémoire dans les romans de Neil M. Gunn, Besançon, Presses universitaires de Franche-Comté.

KINGSHILl Sophia \& WESTWOOD Jennifer, 2014, The Fabled Coast, London, Penguin.

MARIN Louis, 1997, Détruire la peinture, Paris, Flammarion.

SINCLAIR John, 1831, “American Correspondence, XXV Miscellaneous Correspondence”, in The Correspondence of the Right Honourable, 2: With Reminiscences of the Most Distinguished Characters Who Have Appeared in Great Britain, and in Foreign Countries, During the Last Fifty Years, London, Henry Colburn and Richard Bentley.

VeESER H. Aram (ed.), 2013, The New Historicism [1989], London, Routledge.

\section{Electronic resources}

\section{Reference books}

The American Heritage Idioms Dictionary, 2002 [1995], Houghton Mifflin Company, <www.dictionary.com/browse/herring> (consulted 24 Sept. 2016).

Chambers Dictionary, New Delhi, Allied Chambers, online version (consulted 24 Sept. 2016).

\section{Art and culture}

COAKLEY Frances (ed.), 1914, "The King of the Sea”, A Book of Manx Songs (for WW1 troops), 1914, <www.isle-of-man.com/manxnotebook/fulltext/ms1914/p03.htm> (consulted 3 Oct. 2016).

FISHER Mark, “The Silver Darlings, 8 Sept. 2009”, <www.theguardian.com/stage/2009/sep/08/ silver-darlings-review> (consulted 5 Oct. 2016).

FISHER Philip, "Silver Darlings", <www.britishtheatreguide.info/otherresources/fringe/ fringe10-50.htm\#silver> (consulted 30 Sept. 2016).

,$-<$ https://edinburghfestival.list.co.uk/article/27955-the-silver-darlings/> (consulted 30 Sept. 2016).

,$-<$ https://edinburghfestival.list.co.uk/event/10003661-the-silver-darlings/ (consulted 30 Sept. 2016).

"Folly Bridge", The Herring Song, Harrin's Heid, <www.youtube.com/watch?v=8t8NP-OM22g> (consulted 2 Sept.2016).

KINGHORN Ross, "Scotland's Arts and Culture”, TVBOMB, <http://www.tvbomb.co.uk/review/thesilver-darlings-2/>.

"Manx fairy Tales: How the Herring Became King of the Sea" (MorRISON Sophia, 1911, Manx Fairy Tales, London), <http://www.isleofman.com/welcome/history/mythology-and-folklore/manxfairy-tales/how-the-herring-became-king-of-the-sea/> (consulted 30 Sept. 2016).

MORRISON Sophia, 1911, Manx Fairy Tales, London, David Nutt, p. 26, <www.archive.org/stream/ manxfairytales00morr\#page/n7/mode/2up> (consulted 30 Sept. 2016). 
VOGELAER Pieter, The Dutch herring fleet (Hollandse haringvloot), pen and ink $84 \mathrm{~cm}$ x $114 \mathrm{~cm}$ work

(Schilderijencollectie, Rijksmuseum), <www.geheugenvannederland.nl> (consulted 22 Sept. 2016).

\section{Society and History}

ANDERSON-WOOD Jocelyn, "Herring Girls", <www.girlmuseum.org/herring-girls/> (consulted 6 Oct. 2016).

"Scots author reveals how herrings created jobs and wealth before leaving heartache in their wake when they vanished", Daily Record, <www.dailyrecord.co.uk/news/scottish-news/scotsauthor-reveals-how-herrings-6670093>.

"Scotch Fisher Girls at Yarmouth. 1935 Great Yarmouth, Norfolk", East Anglian Film Archive (EAFA), $<$ www.eafa.org.uk/catalogue/181>.

Silver Darlings: The History of Herring Fishing on the East Coast of Scotland, <www.historyshelf.org/secf/silver/01.php> and <www.historyshelf.org/secf/silver/13.php> (consulted 22 Sept. 2016).

\section{Journals and newspapers}

HALLBERG-CAMPBELl Johan, "Last of the Silver Darlings”, Anglers Journal, 25 Aug. 2015, $<$ www.anglersjournal.com/adventure/silver-darlings/> (consulted 6 Oct. 2016).

Other

"Le réalisme au cinéma", Séquences : la revue de cinéma, 1959, no. 18, <www.erudit.org/fr/revues/ sequences1081634/1959-n18-sequences1157834/52165ac/>.

Coffman Elesha, "What is the origin of the Christian fish symbol?', Christian History, $<$ www.christianitytoday.com/history/2008/august/what-is-origin-of-christian-fishsymbol.html> (consulted 30 Sept. 2016).

\section{NOTES}

1. "Since the Latin source of this word [text], he says, is texere meaning to weave, and the noun textus meaning 'tissue', 'weaving', or 'web', then perhaps texts should be looked at as 'intermittent and extensible structures formed by a weaving together of stands'." (Barry, 2007, p. 37)

2. Red herring refers to a particularly strong kipper, a fish that has been strongly cured in brine and/or heavily smoked. This process makes the fish particularly pungent smelling and, with strong enough brine, turns its flesh reddish.

3. “Old English hering (Anglian), hæring (West Saxon), from West Germanic heringgaz (cf. Old Frisian hereng, Middle Dutch herinc, German Hering), of unknown origin, perhaps related to or influenced in form by Old English har 'gray, hoar', from the color, or to old High German heri 'host, multitude' from its large schools" (<www.dictionary.com/browse/red-herring>).

4. Nowadays, herring is not as popular as it was although its healthy oils are bought in expensive food supplements.

5. Cf. footnote 3 .

6. Cf. footnote 3 . 


\section{ABSTRACTS}

From the Middle Ages onwards, herring-one of the most used marine resources-has provided Scotland with a precious, cheap, plentiful and nutritious source of food. Fishing was first a subsistence activity, and it then developed into an industry. Once in unbelievable abundancethe old German word 'herring' means 'multitude'-herring attracted thousands of boats from all over Europe to the Scottish waters, and at the peak of the herring boom, Britain exported a quarter of a million tonnes a year.

Political and religious institutions, the Crown and Government supported and encouraged the economic sector through exclusive rights, licences and bounties. Yet, severe competition and intensive methods of fishing endangered the species.

Silver-coloured, as slick and bright as mercury, the fish has poetically been nicknamed 'silver darlings'. This has become the title chosen by Neil Gunn for one of his novels (1941), by Peter Arnott's for its dramatic adaptation and for Clarence Elder's film (1947). The decrease of the natural food source magnified its legendary dimension through folklore, songs and tales. The National Museum of Scotland exhibited a piece called The Last of the Silver Darlings by glassmaker and storyteller James Maskrey (2014).

This paper focuses on the importance of silver darlings in Scottish History, and on their aesthetic and emblematic use.

Depuis le Moyen Âge, les harengs - l'une des ressources marines les plus usitées - a fourni à l'Écosse une source alimentaire précieuse, économique et abondante. La pêche a d'abord été un moyen de subsistance puis elle s'est développée en une activité industrielle. Autrefois incroyablement abondants - en vieil allemand le mot hareng signifie multitude - les harengs ont attiré des milliers de bateaux de l'Europe entière vers les eaux écossaises et, à l'apogée de l'expansion du hareng, la Grande-Bretagne exportait un quart de million de tonnes par an.

Les institutions politiques et religieuses, la Couronne et le Gouvernement ont soutenu et encouragé ce secteur économique par le biais de droits exclusifs, de licences et de bonus. Cependant, la concurrence âpre et les méthodes de pêche intensives ont mis l'espèce en danger. De couleur argentée, aussi glissant et brillant que le mercure, ce poisson a reçu le surnom de silver darlings (" chéris argentés »). Neil Gunn l'a donné en titre à l'un de ses romans (1941), Peter Arnott's à son adaptation dramatique et Clarence Elder à son film (1947). Le déclin de cette source alimentaire naturelle a magnifié sa dimension légendaire grâce au folklore, aux chansons et aux contes.

Le musée national d'Écosse a exposé l'œuvre du souffleur de verre et conteur James Maskrey intitulée The Last of the Silver Darlings en 2014.

Cet article s'intéresse à l'importance des harengs dans l'histoire de l'Écosse ainsi qu'à leur utilisation esthétique et emblématique.

\section{INDEX}

Mots-clés: hareng, Silver Darlings, contextualité, intersémioticité, intertextualité

Keywords: Herring, Silver Darlings, contextuality, intersemioticity, intertextuality 


\section{AUTHOR}

\section{DANIÈLE BERTON-CHARRIÈRE}

Université Clermont Auvergne, CERHAC, IHRIM-UMR 5317 CNRS.

Danièle Berton-Charrière is Professor Emerita, IHRIM-UMR 5317 CNRS, Université Clermont

Auvergne, France. She wrote a French "Thèse d'État" on Cyril Tourneur and on computer assisted analysis, and has edited and published books and papers on the Renaissance, on drama and theatre of all periods, more particularly Elizabethan and Jacobean, on intersemioticity, and on computer assisted lexicometry and stylostatistics. She has also translated plays including contemporary Scottish writing, for the stage. Some of her most recent work includes the collective volume Témoigner : flibuste, piraterie et autres courses, de la Renaissance aux Lumières (Cahier de l'équipe Réforme Contre Réforme, no. 11 PUBP, Clermont-Ferrand, 2015), with Sophie Jorrand and Monique Vénuat, as well as the articles "Pleasure Reconciled to Virtue (Ben Jonson, 1618)", in Jean-Claude Colbus and Brigitte Hébert (eds), Approches critiques du plaisir (1450-1750),

L'Harmattan, Historiques, Paris, 2015; “'Land-Scaping' the Scottish Stage and Drama”, in Philippe Laplace (ed.), Environment and Ecological Readings. Nature, Human and Posthuman Dimensions in Scottish Literature and Arts (18th-21st c.), Presses universitaires de Franche-Comté, 2015;

“Transtextualité, intersémioticité et pensée visuelle : chassés-croisés picturaux, textuels et sensoriels dans The Spanish Tragedy (T. Kyd) et The Atheist's Tragedy (C. Tourneur)", in Yona Dureau (ed.), Synesthésie et transposition d'art dans la littérature et les arts de l'Angleterre élisabéthaine, Paris, Genève, Éditions Champion, 2015. 